\title{
DEMOGRAFICKÁ PROJEKCIA MALÝCH ÚZEMNÝCH CELKOV: APLIKÁCIA NA OBCE BRATISLAVSKÉHO FUNKČNÉHO MESTSKÉHO REGIÓNU
}

\author{
Pavol Ďurček* \\ * Univerzita Komenského v Bratislave, Prírodovedecká fakulta, Katedra ekonomickej a sociálnej geografie, \\ demografie a územného rozvoja, Ilkovičova 6,84104 Bratislava, Slovensko \\ pavol.durcek@uniba.sk
}

\begin{abstract}
Demographic projection for small territories: application to municipalities of the Bratislava functional urban region

The main aim of this paper is to present the demographic projection up to the year 2024 at the municipal level of the Bratislava functional urban region. The methodology of our demographic estimate is based on the Hamilton-Perry method which we modified for the application for small statistical units. Testing of accuracy is based on several trend extrapolations of the total population. The results of our projection can be summarized as follows. The core of the urban region will stagnate, or grow slightly. On the one hand the high increase in the population in the nearest hinterland of Bratislava is estimated, on the other hand, the population in more remote municipalities will decrease. The paper also offers a practical application of using estimated population data in a simplified availability analysis.
\end{abstract}

Key words: demographic projection, age structure, Hamilton-Perry method, trend extrapolation methods, Bratislava functional urban region

\section{ÚVOD}

Na Slovensku doposial' chýba práca, v ktorej by sa predpovedal budúci demografický vývoj na úrovní obcí širšieho územia, či kompaktného regiónu. Dôvody, prečo to tak je, sú pravdepodobne viaceré. Dovol'ujeme si povedat', že asi najzávažnejším z nich je vysoká náhodnost' predikcie v takých malých mierkach ako sú obce. Avšak akademická zvedavost' núti pozriet' sa na tento problém a odpovedat' na otázku: Do akej miery sú demografické projekcie v takej malej mierke možné a aká je ich potenciálna presnost? Práve preto je hlavným ciel'om nášho príspevku vypracovanie demografickej projekcie pre horizont 31.12.2024 na úrovni obcí bratislavského mestského funkčného regiónu. Metodika projekcie je založená na Hamiltonovo-Perryho metóde, nazvanej podla autorov, ktorí ju systematicky vyložili v spoločne publikovanej štúdii (Hamilton a Perry1962). Táto metóda bola špeciálne vyvinutá na demografickú projekciu v malých mierkach a my sme si ju mierne upravili pre naše potreby. Náš postup budeme verifikovat' niekol'kými nezávislými projekciami celkovej populácie zloženými na trendových modeloch. Následne uvedieme, o kol'ko percent sa celkový počet obyvatel'ov, získaný pomocou HamiltonovoPerryho metódy, zhoduje s výsledkami najpresnejšieho trendového modelu.

Aký je však praktický zmysel demografických projekcií v lokálnej mierke? Domnievame sa, že opodstatnenost' poznania budúceho demografického vývoja v lokálnych mierkach spočíva hlavne $\mathrm{v}$ jestvujúcej vnútroštátnej geografickej diferenciácii, ktorá neumožñuje efektívne zavádzanie celonárodných opatrení a vyžaduje cielené riešenia len vo vybraných problematických regiónoch, ktoré môžu mat' odlišný demografický vývoj ako celý štát. V kompetencii miestnych či regionál- 
nych samospráv je nastavovanie kapacít predškolských zariadení, základných škôl, seniorských stacionárov a domovov dôchodcov, či d’alších verejných obecných služieb - napr. obecnej knižnice či kultúrneho strediska. Viaceré mestá zároveň dimenzujú kapacitné pomery vo verejnej doprave na základe zistení budúceho demografického vývoja (Patel et al. 2002). Bez poznania budúceho vývoja v lokálnej mierke možno manažovanie týchto verejných služieb označit' za riskantné až nezodpovedné.

Výsledky našej demografickej projekcie zahŕňajú počet obyvatel’ov, relatívny a absolútny celkový prírastok od prahu po horizont projekcie. Zároveň pomocou indexu ekonomického zat’aženia a podielu hlavných vekových skupín zhodnotíme vekovú štruktúru v horizonte projekcie. Výsledky sú prezentované na úrovní obcí, ako aj sumárne za urbanizačné zóny mesta Bratislava definované v práci Švedu (2011). Nakoniec uvádzame konkrétny príklad využitel'nosti našej demografickej projekcie. Zjednodušene poukážeme na to, ako je dôležité poznat' budúci počet obyvatel'ov vo vybraných vekových skupinách v dosahovom území výstavby nových cestných komunikácií - konkrétne dial'ničný obchvat D4 a rýchlostná cesta R7.

\section{DEMOGRAFICKÉ PROJEKCIE V MALÝCH MIERKACH}

Projekcia budúceho demografického vývoja je nepochybne jedným z najpraktickejších tematických okruhov demografie. Predpovedanie budúceho vývoja sa najviac týka častí spoločnosti, ktoré sú priamo prepojené s demografickými charakteristikami. Ide hlavne o pracovný trh, sociálne služby a zdravotníctvo (Bleha et al. 2018). Demografické projekcie v lokálnej mierke majú voči národnej úrovni niekol'ko špecifík (Wilson a Rowe 2011). Asi najvýraznejším z nich je nutnost' využívat' zjednodušené projekčné postupy, ktoré nie sú také náročné na dáta ako prognózy na národnej úrovni. Zjednodušovanie postupov je nutné na znižovanie rizika nepresnosti predpovede, ktoré je pri príliš zložitých modeloch väčšie. Ďalším špecifikom demografických projekcií v subnárodnej mierke je znižovanie rizika nepresnosti prostredníctvom projektovania budúceho vývoja na kratší časový interval.

Aj napriek tomu, že demografickým projekciám na úrovni obcí, resp. miestnych samospráv, sa nevenuje taká pozornost' ako projekciám na úrovni štátov, uvádzame viacero štúdií, ktoré riešia túto problematiku. Z metodického hl'adiska nás zaujala práca Issermana (1993), v ktorej bol použitý medziregionálny prístup v kohortnokomponentom modeli. Tento postup bol aplikovaný na 55 „,counties“ (obdoba našich okresov) amerického štátu Západná Virgínia. Isserman považuje za kl’účový demografický proces migráciu, ktorá v lokálnych mierkach výrazne formuje počet obyvatel'ov. V práci autorov Wilson a Rowe (2011) boli hodnotené výsledky siedmich demografických projekcií za austrálsky štát Queensland a jeho lokálne samosprávy. Autori uvádzajú, že jednoduchšie projekčné modely mali presnejšie výsledky a v záverečnej časti práce sú uvedené postupy, akými by sa dali chyby demografických projekcií znížit'. Swanson et al. (2010) aplikovali aj nami použitú Hamiltonovu-Perryho metódu pre mesto Las Vegas a municipality v jeho zázemí. Vel'mi špecifickou je práca od autorov Smith a Nogle (1997), ktorí predstavili postup na vypočítanie celkového počtu a vekovo-pohlavného zloženia hispánskej populácie v miestnych oblastiach Floridy. Viac metodický charakter má práca autorov Baker et al. (2013), ktorí porovnávali Hamiltonovu-Perryho metódu s kohortno-komponentnou metódou založenou na parciálnych mierach narodených, zomretých a me- 
dziobecnej migrácii. Autori pomocou oboch metód odvodzujú počet obyvatel'ov podl'a pohlavia a veku v tzv. „,housing-unit“ v USA, čo možno chápat' ako obdobu našich základných sídelných jednotiek. Dalej bola Hamiltonova-Perryho metóda použitá na modelovanie základných demografických štruktúr miestnych municipalít metropolitného regiónu Montrealu v období rokov 2006 - 2031 (Marois a Bélanger 2015). Pät' projekčných postupov zohl'adňujúcich rozdielne prístupy sledovania migrácie je uvedených v publikácii od Wilsona (2016). Analýza je realizovaná na príklade 67 miestnych samospráv austrálskeho Nového Južného Walesu.

Aj v česko-slovenskom priestore vzniklo niekol'ko prác, ktoré sa venujú problematike demografických projekcií na úrovni obcí. Ich spoločným prvkom je to, že nehodnotia jednotlivé obce na rozsiahlejšom území. Demografický vývoj je spravidla predpovedaný len pre väčšie mestá, kde je neurčitost' budúcich demografických pomerov nižšia. Konkrétne môžeme spomenút' prognostický odhad počtu obyvatel'ov v mestskej časti Praha-Zličín (Burcin a Kučera 2007) či mestskej časti Brno-Bystrc (Burcin a Kučera 2007) alebo mesta Beroun (Burcin et al. 2008). Na Slovensku bola vypracovaná štúdia demografického potenciálu hlavného mesta Slovenskej republiky Bratislava (Bleha et al. 2014). Zároveň pri analyzovaní demografického vývoja najväčších slovenských miest (viac ako 50 000-tisíc obyvatel'ov) bola vypracovaná aj demografická prognóza (Šprocha et al. 2017). Špecifický typ predstavujú projekcie tzv. nodálnych regiónov. Burcin et al. (2013a) zostavili demografickú projekciu za spádové územie Dolných Břežan. Rovnaký autorský kolektív navrhol aj projekciu za oblast' suburbánnej zóny Prahy (Burcin et al. 2013b). Vlastnosti extrapolačných populačných modelov na vzorke funkčných regiónov Slovenska zhodnotili vo svojej práci Bezák a Holická (1995). Tento vedecký článok má síce metodický charakter, ale jeho výsledky boli aplikované v konkrétnej empirickej analýze na úrovni obcí v práci Holická (1997).

Potenciál demografických projekcií vyplýva aj z niektorých legislatívnych procesov a nariadení. Z ustanovenia $\S 11$ ods. stavebného zákona vyplýva, že na Slovensku sú obce s viac ako 2000 obyvatel'mi povinné mat' územný plán obce (zákon číslo 293/2014 Z. z). Preto viaceré územné plány obcí, alebo dokonca len územné plány zón, obsahujú aj projekciu počtu obyvatel'ov. Tieto demografické predpovede sú relatívne jednoduché a často využívajú princíp koeficientu počtu obyvatel'ov na jednotku obytnej plochy alebo len extrapolovanie budúceho stavu na základe matematickej funkcie. Nevýhodou je, že výsledkom takýchto postupov je iba celkový počet obyvatel'ov (napr. Dudášová et al. 2008). Ako uvádzajú Bleha a Farbiaková (2017), postupne sa strategické dokumenty obcí z hl'adiska demografickej analýzy a predpovedania budúceho vývoja zlepšujú. Stále viac plánovacích dokumentov (aj programov hospodárskeho a sociálneho rozvoja) obsahuje aj predpokladané počty obyvatel'ov aspoň podl'a vekových skupín či pohlavia. Práve pre potreby územného plánovania v malých mierkach vznikli aplikačné výstupy českej akademickej sféry. Napríklad demografická projekcia počtu žiakov v materských a základných školách pre malé územne celky (Fiala a Langhamrová 2017) a dokonca internetová aplikácia, ktorá dokáže vypočítat' budúci demografický vývoj a nároky na sociálnu infraštruktúru pre všetky obce ČR (Špačková a Burcin 2017). Táto aplikácia hodnotí zmeny pôrodnosti a úmrtnosti $\mathrm{v}$ strednodobom horizonte a zároveň na základe bytovej výstavby dokáže predpokladat' aj úroveň imigrácie. Naša štúdia má ambíciu pozriet' sa na problematiku projekcie počtu obyvatel’ov na úrovni obcí a obohatit' tento vel'mi praktický segment demografie. 


\section{DÁTA A METÓDY}

Pri realizácii demografickej projekcie používame Hamiltonovu-Perryho metódu (zjednodušene H-P metóda) - Hamilton a Perry (1962). Dôležité je upozornit', že H -P metóda $v$ základnej podobe nepočíta so zmenami v intenzite jednotlivých demografických procesov (pôrodnost', migrácia a úmrtnost'), a preto je vhodnejšia na predpovedanie budúceho vývoja len v kratších časových horizontoch (5 až 10 rokov), resp. v podmienkach, ked' sa nepredpokladá zmena intenzity jednotlivých procesov (Boyce 1977). H-P metóda funguje na báze posúvania početnosti jednotlivých vekových skupín do vyššieho veku, ked' je početnost' daných vekových skupín upravovaná podl'a tzv. indexu zmeny vekovej skupiny (cohort-change ratio CCR). Matematický zápis, ktorý platí pre druhú až predposlednú vekovú skupinu, má nasledujúci tvar:

$$
P_{i}(t+h)=P_{i-1}(t) \cdot r_{i-1},
$$

kde $P_{i}(t+h)$ predstavuje počet obyvatel'ov vo vekovej skupine $i$ v projekčnom okamihu $t+h, P_{i-1}(t)$ je počet obyvatel'ov vo vekovej skupine $i-1 \mathrm{v}$ okamihu $t$ a $r_{i-1}$ je index zmeny vekovej skupine $i-1$.

Premenná $t$ predstavuje prah projekcie, resp. okamih začiatku projekcie. Inak povedané, je to dátum, ku ktorému máme najnovšie reálne dáta. V našom prípade je to dátum 31. 12. 2019. Premenná $h$ je časové obdobie, na ktoré sa „,chceme pozriet"“ do projekčnej budúcnosti. Je optimálne, aby sa časové obdobie $h$ zhodovalo s rozpätím jednotlivých vekových skupín, resp. $h$ bolo spoločným násobkom rozpätia vekových skupín. Ak toto nie je dodržané, je potrebné vykonávat' dodatočné aproximácie k požadovanému dátumu projekcie, čo môže znižovat' presnost' projekcie (Bleha 2006, Bleha a Vaňo 2007 a Bleha a Šprocha 2015). V našom prípade je časové obdobie $h 5$ rokov. Zároveň používame 5-ročné vekové skupiny $(0-4,5$ $-9, \ldots 80-84,85+)$, ktoré označujeme ako $i$. Okamih $t+h$ (horizont projekcie) následne predstavuje dátum 31. 12. 2024.

Index zmeny vekovej skupiny $i$ sa počíta nasledujúcim spôsobom:

$$
r_{i-1}=\frac{P_{i}(t)}{P_{i-1}(t-h)},
$$

kde $P_{i}(t)$ je počet obyvatel'ov vo vekovej skupine $i$ v okamihu $t, P_{i-1}(t-h)$ je počet obyvatel'ov vo vekovej skupine $i$ v poradí o jedna menšej ako $i$ (napríklad ak $i$ je $60-64$, tak $i-1$ je $55-59$ v časovom okamihu $t-h$. V našom prípade predstavuje časový okamih $t-h$ dátum 31. 12. 2014.

Pôvodná H-P metóda slúžila na projekciu vekovej štruktúry $\mathrm{k}$ budúcemu dátumu sčítania, a preto bola upravená na univerzálnejšie použitie (napr. v práci Smith et al. 2013). Viacero úprav sa týka práve výpočtu vel'kosti prvej vekovej skupiny. Tento výpočet bol podl'a Hamiltona a Perryho (1962) založený na špecifických mierach plodnosti, ktoré sú len zriedkakedy dostupné za úroveň obcí či menších regiónov. Preto sme si v našej práci zvolili postup vychádzajúci z práce autorov Shryock a Siegel (1973), ktorý umožňuje výpočet vel'kosti prvej vekovej skupiny na základe tzv. indexu plodnosti (Child-woman ratios - CWR). Tento index zohl'adňuje pomer medzi početnost'ou prvej vekovej skupiny a počtom žien v reprodukčnom veku. Vzhl'adom na to, že v sledovanom regióne sa až $95 \%$ pôrodov uskutočn̆uje vo veku 20 až 39 rokov, zredukujeme vo výpočte indexu plodnosti 
početnost' žien v reprodukčnom veku iba na túto vekovú skupinu ${ }^{1}$. Matematicky zápis tejto úpravy je nasledovný:

$$
r_{c h}=\frac{P_{0-4}(t)}{P_{20-39}^{f}(t)},
$$

kde $r_{c h}$ predstavuje index plodnosti, $P_{0-4}(t)$ je počet osôb vo veku 0 až 4 v časovom okamihu $t$ a $P_{20-39}^{f}(t)$ je počet žien vo veku 20 až 39 rokov v časovom okamihu $t$. Následne indexom plodnosti prenásobíme projektovaný počet žien vo veku 20 až 39 a tým určíme počet osôb (detí) v najmladšej vekovej skupine. Tento krok má nasledujúci matematický zápis:

$$
P_{0-4}(t+h)=P_{20-39}^{f}(t+h) \cdot r_{c h},
$$

$P_{0-4}(t+h)$ je počet osôb vo veku 0 až 4 roky v časovom okamihu $t+h . P^{f}{ }_{20-39}(t+h)$ je projektovaný počet žien vo veku 20 až 39 rokov v časovom okamihu $t+h$. Rovnako ako pre prvú skupinu, aj pre výpočet vel'kosti poslednej vekovej skupiny sa musí použit' odlišný postup. Dôvodom je skutočnost', že najstaršia veková skupina bežne nemá určenú hornú hranicu intervalu. Nižšie uvádzame našu úpravu rovnice prevzatú z práce Smith et al. (2001):

$$
P_{\max }(t+h)=\left[P_{\max }(t)+P_{\max -1}(t)\right] \cdot r_{\max },
$$

kde $P_{\max }(t+h)$ predstavuje počet obyvatel'ov v najstaršej vekovej skupine (v našom prípade je to $85+)$ v projekčnom okamihu $\mathrm{t}+\mathrm{h}$. $P_{\max }(t)$ je počet obyvatel'ov v najstaršej vekovej skupine v okamihu $t . P_{\max -1}(t)$ je počet obyvatel'ov v predposlednej vekovej skupine (v našom prípade 80 až 84) v okamihu $t$ a $r_{\max }$ je index zmeny najstaršej vekovej skupine, ktorý sa počíta nasledujúcim spôsobom:

$$
r_{\max } \frac{P_{\text {max }}(t)}{P_{\max }(t-h)+P_{\max -1}(t-h)},
$$

kde $P_{\max }(t)$ je počet obyvatel'ov $\mathrm{v}$ najstaršej vekovej skupine $\mathrm{v}$ okamihu $t$, $P_{\max }(t-h)$ je počet obyvatel'ov v najstaršej vekovej skupine v časovom okamihu $t-h$ a $P_{\max -1}(t-h)$ je počet obyvatel'ov v predposlednej vekovej skupine v časovom okamihu $t-h$.

Výsledky našej projekcie budeme overovat' niekol'kými nezávislými projekciami celkovej lokálnej populácie. Tento postup je odporúčaný pri použití H-P metódy aj v práci Smith et al. (2013). Dôvodom overovania je fakt, že viacerí autori (Swanson et al. 2010, Baker et al. 2013 a Marois a Bélanger 2015) konštatovali, že v rýchlo rastúcich lokalitách aplikácia nemenných indexov zmeny vekových skupín často vedie $\mathrm{k}$ vel'kej chybovosti.

Konkrétne aplikujeme pät' extrapolačných modelov (lineárny, geometrický, exponenciálny, logistický a kvadratický), z ktorých vyberieme ten, ktorý bude vyka-

\footnotetext{
${ }^{1} \mathrm{~K}$ tejto redukcii sme pristúpili preto, že pred dosiahnutím 20 . roku života, ako aj po 40. roku je fertilita minimálna. Zahrnutie početnosti týchto vekových skupín výsledky nezlepší a môže ich len skreslit'. V období rokov 2015 až 2019 sa v daných vekových skupinách narodil nasledujúci podiel detí: 20 až 24 rokov - 7,2 \% detí, 25 až 29 rokov - 26,0 \% detí, 30 až 34 rokov - 40,4 \% detí a 35 až 39 rokov - 21,2 \% detí (ŠÚ SR 2019).
} 
zovat' najväčšiu zhodu s reálnymi údajmi ${ }^{2}$. Každý model bude odvodený na základe údajov o celkovom počte obyvatel'ov za každý rok obdobia rokov 2014 až 2019. Zhodu každého modelu s reálnymi údajmi budeme vyjadrovat' pomocou koeficientu determinácie. Najpresnejší model následne použijeme na extrapoláciu celkového počtu obyvatel'ov v okamihu horizontu projekcie a porovnáme ho s výsledkami projekcie vekového zloženia. Pre každú obec v sledovanom regióne uvedieme, o kol'ko percent sa celkový počet obyvatel'ov získaný pomocou H-P metódy zhoduje s výsledkami najpresnejšieho extrapolačného modelu.

Výsledky našej demografickej projekcie spolu s hodnotami výsledkov celkového počtu obyvatel'ov podl'a najpresnejšieho trendového modelu ponúkame na internetovom odkaze uvedenom sa v závere článku.

Vymedzenie bratislavského funkčného regiónu preberáme z práce Bezák (2000). Zároveň naše výsledky budeme interpretovat' aj za tzv. urbanistické zóny stanovené v práci Šveda (2011). Pre lepšiu orientáciu ich znázorňujeme na obr. 1 a zároveň uvádzame aj začlenenie obcí do jednotlivých urbanizačných zón.
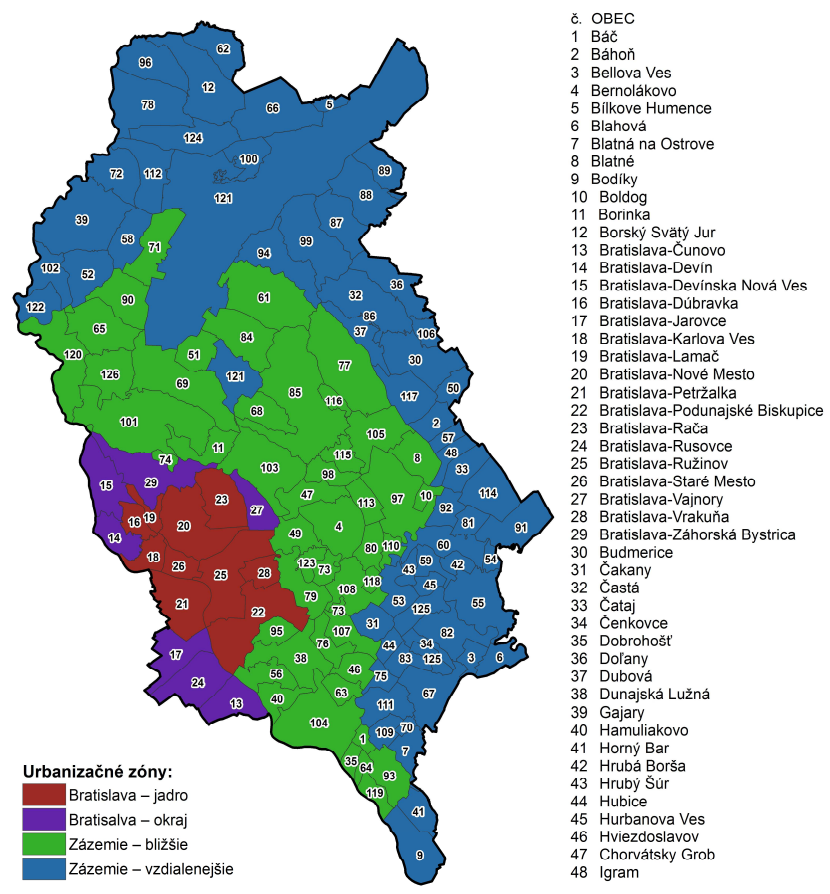

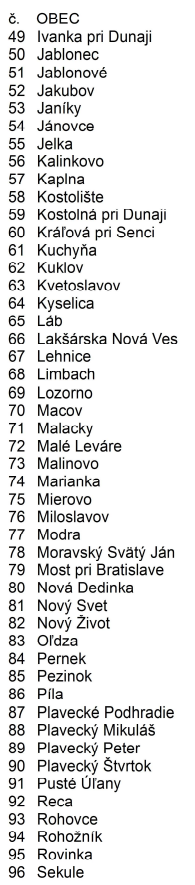

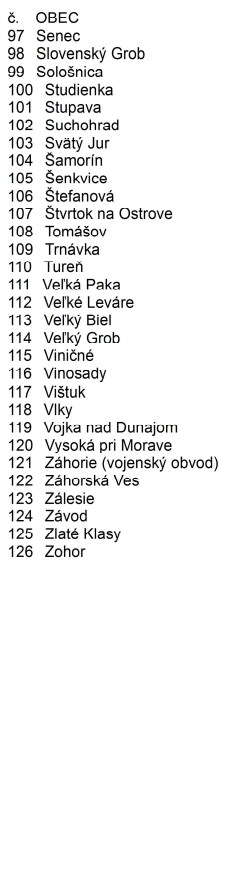

Obr. 1. Priestorové rozloženie obcí bratislavského funkčného mestského regiónu podl'a urbanizačných zón

Zdroj: (Šveda 2011 a ÚGKKSR 2016).

\footnotetext{
${ }^{2}$ Viac k matematickému zápisu a kalibrovaniu jednotlivých trendových modelov v práci Smith et al. (2001).
} 


\section{VÝSLEDKY DEMOGRAFICKEJ PROJEKCIE}

Na základe projekcie pomocou H-P metódy môžeme konštatovat', že počet obyvatel'ov celého regiónu ku koncu roka 2024 bude 757764 osôb. Voči roku 2019 je to zvýšenie o 32480 osôb, čo v relatívnom vyjadrení predstavuje nárast o 4,48 \%. Za predchádzajúce 5-ročné obdobie rokov 2014 až 2019 sa zvýšil počet obyvatel'ov regiónu o 38844 osôb, resp. o 5,66 \%. Z týchto čísel vyplýva, že dynamika rastu celého regiónu sa nebude v projekčnom období rokov 2019 až 2024 výrazne menit', resp. mierne oslabí. Avšak väčšie rozdiely možno očakávat' na úrovni obcí a urbanizačných zón (vid' obr. 2). Čast' Bratislavy, ktorú na základe práce Švedu (2011) označujeme ako jadrovú, vykáže do roku 2024 najnižší relatívny rast, a to $0,65 \%$. V absolútnych číslach to predstavuje nárast o 2613 osôb. Naopak, najväčší relatívny rast zaznamenáva oblast' tzv. bližšieho zázemia Bratislavy, kde sa na základe našich výpočtov má zvýšit' počet obyvatel'ov až o 11,26 \% (22 985 osôb). Druhý najväčší relatívny nárast o 14,34 \% (3 190 osôb) zaznamenáva práve okrajová čast' samotnej Bratislavy. Vzdialenejšie zázemie vykáže druhý najmenší relatívny nárast, a to o 4,43\%, čo predstavuje absolútny rast o 3692 obyvatel'ov. Naše výpočty, ako aj výsledky viacerých prác (Slavík et al. 2011, Bleha et al. 2013 a Novotný 2016) naznačujú, že príčinou tohto rastu (hlavne v oblasti bližšieho zázemia Bratislavy) je kladné migračné saldo, ktoré je sekundárne dopĺn̆ané hodnotami prirodzeného prírastku.

Úroveň presnosti H-P metódy sme testovali pomocou extrapolačných modelov, z ktorých sme vždy vybrali ten, ktorý v období rokov 2015 až 2019 vykazoval najväčšiu zhodu s reálnymi údajmi v celkovom počte obyvatel’ov v každej obci. Najpresnejším modelom sme extrapolovali k okamihu horizontu projekcie, čiže k 31 . 12. 2024, celkový počet obyvatel'ov každej jednej obce. Následne sme porovnali extrapolované hodnoty s výsledkami H-P metódy. Ako najpresnejší sa v prípade 119 obcí ukázal model kvadratickej funkcie (vid’ obr. 3). V troch obciach bol najpresnejší logistický model. V dvoch prípadoch to bol model lineárny a po jedom prípade to boli exponenciálny a geometrický model. V sledovanom regióne sme pomocou H-P metódy vypočítali nižší celkový počet obyvatel'ov ako pomocou trendových modelov. Rozdiel predstavoval 6367 osôb, čo je 0,84 \% z počtu obyvatel'ov vypočítaných H-P metódou. Avšak diferenciácia na úrovni urbanizačných obvodov je väčšia. Najväčšie rozdiely zaznamenáva jadro funkčného regiónu. H-P metóda určila počet obyvatel'ov jadrových častí Bratislavy o 14664 osôb nižší $(-3,64 \%)$ ako model kvadratickej funkcie. Nižšie hodnoty predpokladá H-P metóda aj vo vzdialenejšom zázemí. Rozdiel predstavuje 1236 osôb (-1,42\%). Naopak H-P metóda určuje vyšší počet obyvatel'ov v okrajových častiach Bratislavy a hlavne v bližšom zázemí mesta. V prvom prípade je to kladný rozdiel o 1202 osôb (2,95 \%) a v druhom prípade kladný rozdiel až o 8331 osôb (3,67 \%). Pri celkovom zhodnotení presnosti nášho postupu môžeme uviest', že v 27 obciach je rozdiel medzi výsledkami H-P metódy a najpresnejšieho trendového modelu viac ako $10 \%$. V týchto obciach žije 46722 obyvatel'ov, čo predstavuje $6,1 \%$ z celkového počtu.

Zmeny vo vekovej štruktúre sme vyjadrili pomocou indexu ekonomického zat’aženia (vid' obr. 4). Ku koncu roka 2019 pripadlo na 100 osôb v produktívnom veku viac ako 52 osôb v neproduktívnych vekových skupinách (0 až 14 a 65+). Pre rok 2024 predpokladáme, že sa toto číslo zvýši na 55 osôb. Zaujímavé je zloženie tohto „ekonomického zat’aženia“. Na konci roka 2024 detská zložka stále dosahuje miernu prevahu nad seniorskou a obyvatel'stvo v poproduktívnom veku zvýši svoj 
GEOGRAFICKÝ ČASOPIS / GEOGRAPHICAL JOURNAL 72 (2020) 3, 275-291

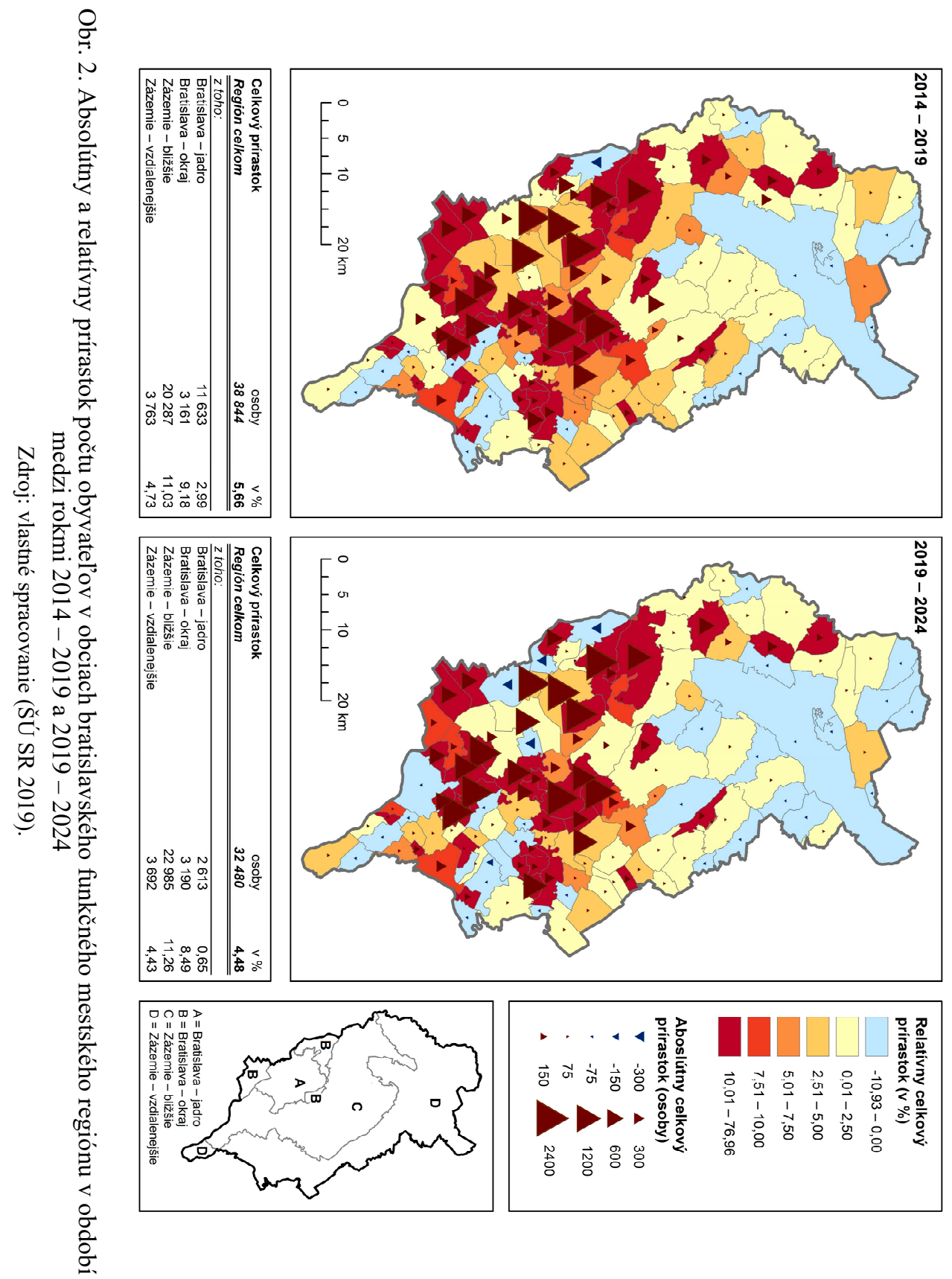


GEOGRAFICKÝ ČASOPIS / GEOGRAPHICAL JOURNAL 72 (2020) 3, 275-291

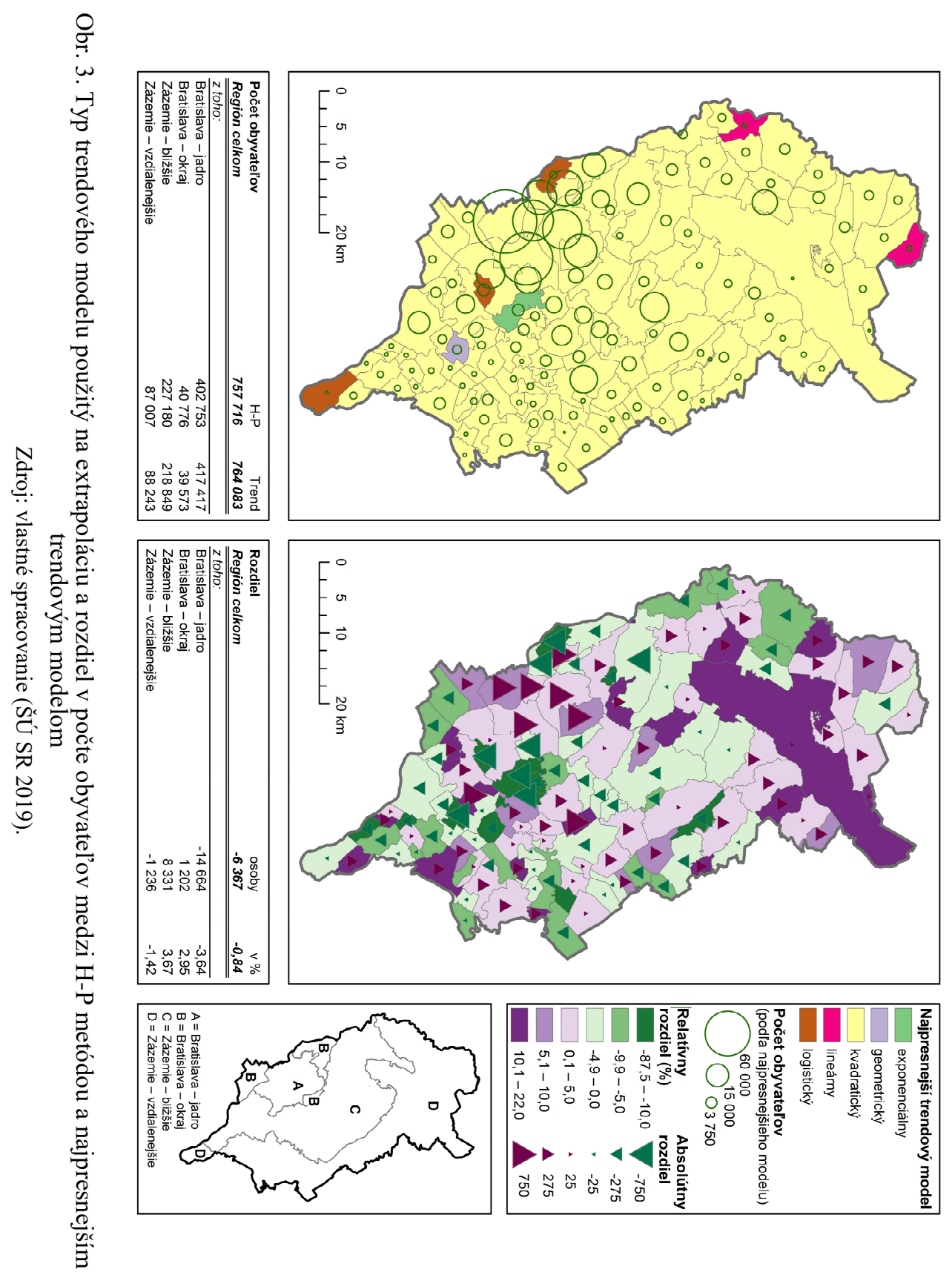


GEOGRAFICKÝ ČASOPIS / GEOGRAPHICAL JOURNAL 72 (2020) 3, 275-291

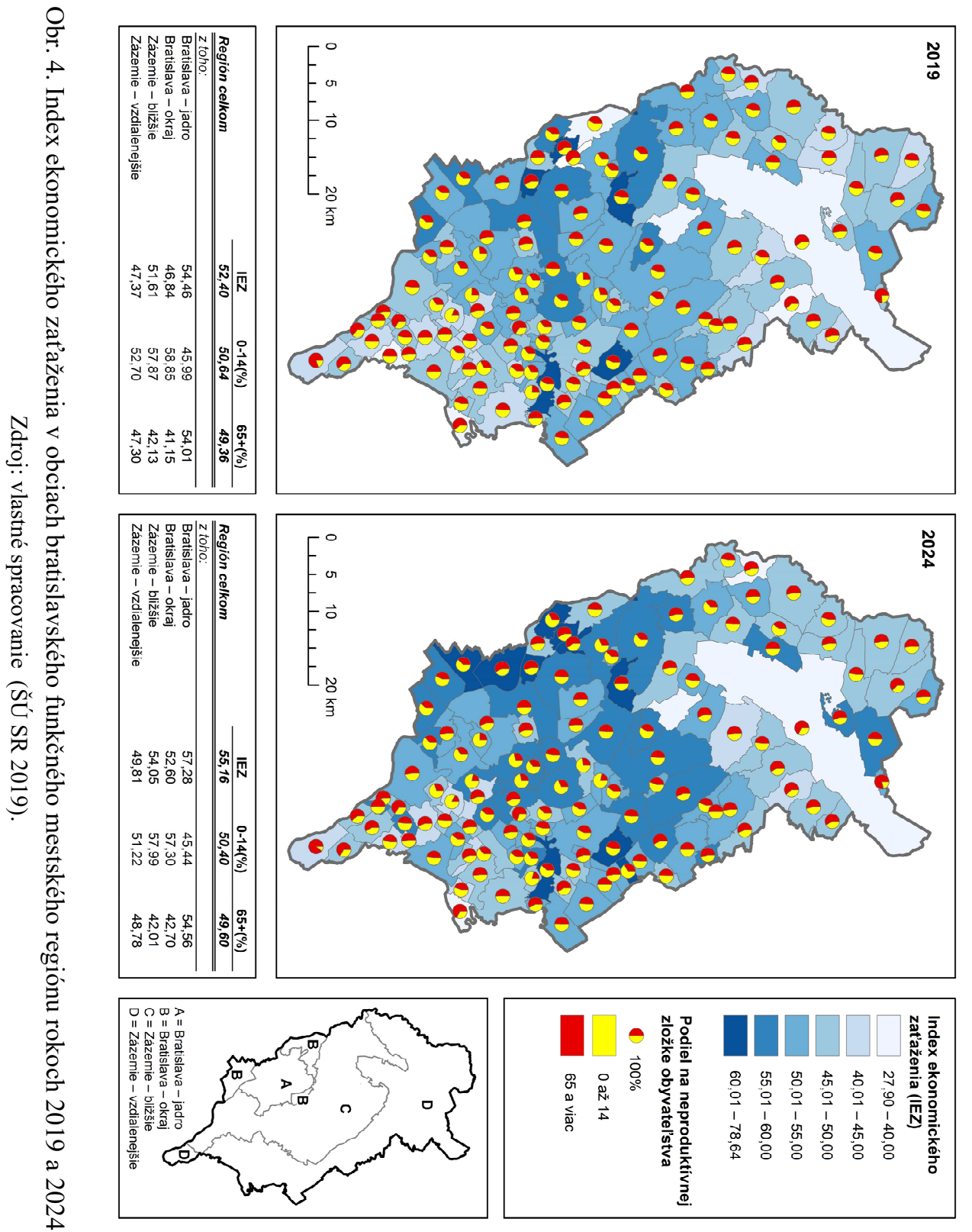


podiel len nepatrne. Tieto čísla možno interpretovat' tak, že ekonomické zat'aženie populácie sa zvýši, ale túto zát’až budú väčšinovo stále tvorit' deti. Stagnácia, resp. slabý rast významu seniorskej zložky obyvatel'stva je v rozpore s celorepublikovým predpokladom (Bleha et al. 2018), ale zároveň je l'ahko vysvetlitel'ný. Ako uvádzajú Bleha et al. (2013), Bratislava so svojím okolím bude atraktívna pre migrantov $\mathrm{v}$ reprodukčnom veku, ktorí budú ašpirovat' na zakladanie rodín. To bude oslabovat' proces starnutia.

Ako nám naznačuje obr. 4, vo vnútri regiónu možno sledovat' diferencovaný vývoj. Jadro Bratislavy zvýši hodnotu indexu ekonomického zat’aženia z 54,46 na 57,28 . Tento rast bude sprevádzaný miernym zvýšením podielu seniorov na neproduktívnej zložke obyvatel'stva. Okrajová čast' Bratislavy zaznamená najväčší rast indexu ekonomického zat'aženia, a to z 46,84 na 52,60. Toto zat'aženie tvorí predovšetkým obyvatel'stvo vo veku $0-14$. Nepatrné zvýšenie podielu detskej zložky očakávame v bližšom zázemí Bratislavy. Táto oblast' zaznamená nárast indexu ekonomického zat'aženia z 51,61 na 54,05. Vo vzdialenejšom zázemí predpokladáme najnižšie ekonomické zat’aženie, ktoré zároveň zaznamená aj najnižší rast z 47,37 na 49,81. Zároveň v neproduktívnej zložke vzrastie podiel seniorov, a to najviac zo všetkých urbanizačných oblastí.

\section{UKÁŽKA VYUŽITEL'NOSTI}

Naša ukážka sa týka oblasti dopravného plánovania. Zistenie skutočnosti, aký počet obyvatel'ov sa bude nachádzat' v určitých vzdialenostiach od nových cestných komunikácií, vie pomôct’ pri odhadovaní využívania/zat’aženia dopravných ciest. Zároveň to umožňuje určit' mieru dosahu environmentálnej zát’aže spôsobovanej hlukom či exhalátmi. To sa samozrejme môže prejavit' na strane dodatočných investičných nákladov na eliminovanie takýchto negatívnych vplyvov (napr. výstavba protihlukových stien). Náš názorný príklad nám dokáže, že nestačí pri projektovaní dopravných stavieb počítat' s konštantným počtom obyvatel'ov, ktorý sa za relatívne krátky čas môže (hlavne v suburbánnych oblastiach) výrazne zmenit'.

V súčasnosti prebiehajúca výstavba dial'ničného obchvatu D4 a rýchlostnej cesty R7 nám poslúžila ako príklad takejto analýzy (vid' obr. 5). Pre dané úseky sme znázornili vzdialenostné zóny v intervale $1 \mathrm{~km}$ (euklidovská vzdialenost') do maximálnej vzdialenosti $5 \mathrm{~km}$. Určili sme, ktoré obce (centroidy intravilánov) sa nachádzajú v daných vzdialenostných zónach. Hodnoty za jednotlivé obce sme kumulovali pre dané vzdialenostné zóny. Konkrétne sme určili celkový počet obyvatel'ov, ako aj počet obyvatel'ov $v$ produktívnom veku (od tejto vekovej skupiny možno očakávat' najčastejšie využívanie daných cestných úsekov) v jednotlivých vzdialenostných zónach. Dané údaje sme uviedli za projekčný prah a horizont. Práve porovnanie údajov oboch týchto okamihov nám môže potvrdit' opodstatnenost' použitia demografických projekcií pri dopravnom plánovaní.

Konkrétne výsledky znázorn̆uje obr. 5. V celej dosahovej zóne (do $5 \mathrm{~km}$ od dial'nice/rýchlostnej cesty) je rozdiel medzi predpovedaným a súčasným počtom obyvatel'ov skoro 19-tisíc. V prípade produktívnej zložky je to číslo vel'mi podobné. Zóna 0,00 až $1,00 \mathrm{~km}$ sa vyznačuje najmenším dosahom. Nachádzajú sa v nej len tri obce s relatívne nízkym počtom obyvatel'ov. Najväčší rozdiel zaznamenali zóny 1,01 až 2,00 km, 3,01 až 4,00 km a 2,01 až 3,00 km. Okrem viacerých vel'kých mestských častí Bratislavy (Ružinov) sa v týchto zónach nachádzajú aj obce zo zázemia Bratislavy (napr. Rovinka a Dunajská Lužná), ktoré sa vyznačujú vel'- 


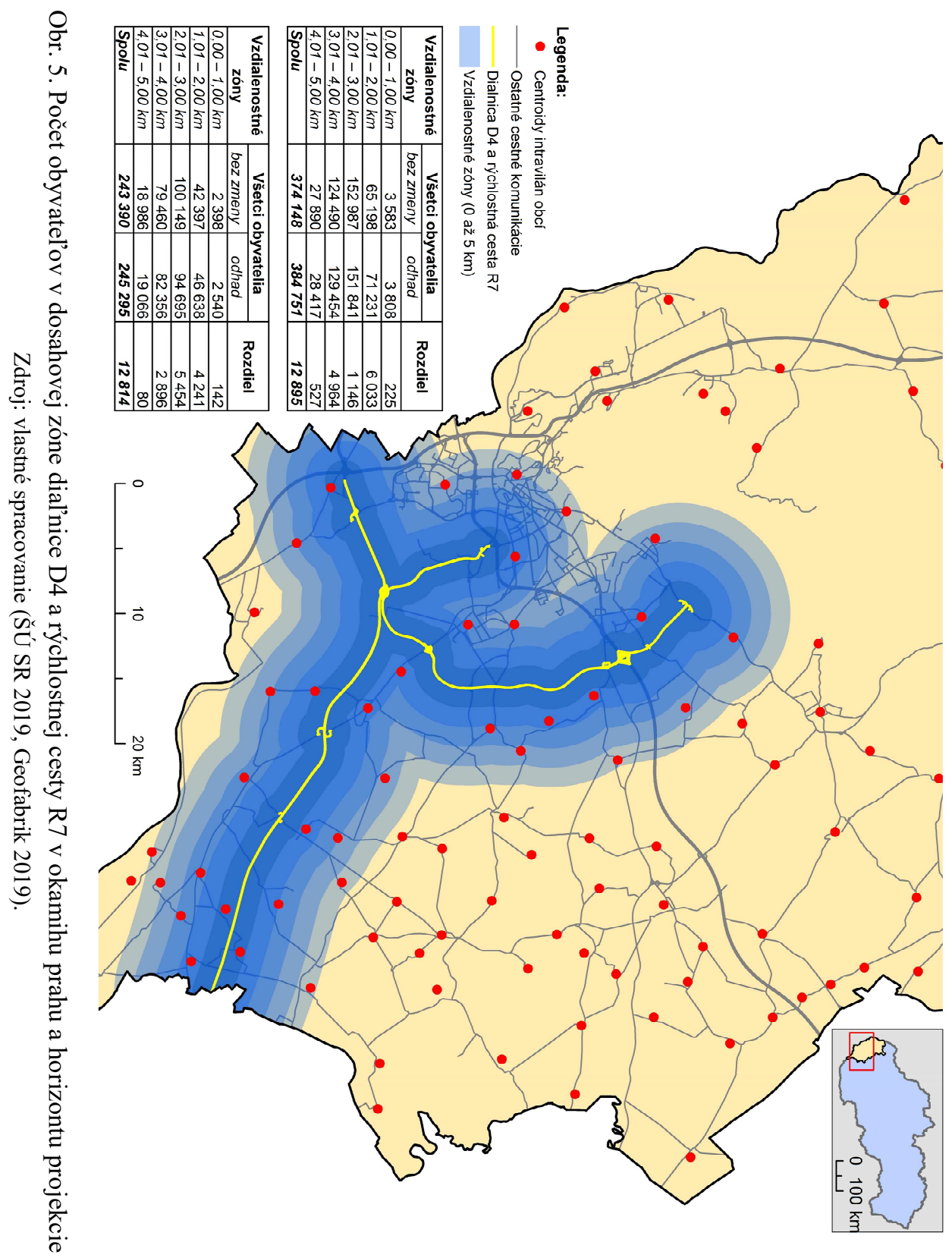


kou mierou rastu počtu obyvatel'ov z dôvodu migrácie. Zóna 4,01 až 5,00 km mala, podobne ako prvá zóna, nižší rozdiel medzi výsledkom z projekcie a súčasnostou. Do týchto zón sa zaradili aj viaceré mestské časti Bratislavy, v ktorých predpokladáme pokles počtu obyvatel’ov, a preto je zmena menej výrazná. Výsledky našej analýzy naznačujú, že v nami definovanom dosahovom území D4 a R7 môže dôjst' k pozorovatel'ným zmenám počtu obyvatel'ov.

\section{ZÁVER}

Hlavným ciel'om bolo realizovat' demografickú projekciu ku koncu roka 2024 na úrovni obcí bratislavského mestského funkčného regiónu. Okrem toho sme pomocou zjednodušenej analýzy dostupnosti úsekov D4 a R7 chceli poukázat' na možnosti využitia takýchto projekcií.

Celkovo by sme mohli naše výsledky zhrnút' nasledujúco. Do roku 2024 pribudne vo funkčnom regióne skoro 39-tisíc osôb. Najväčší populačný nárast možno očakávat' v okrajových mestských častiach Bratislavy a v jej najbližšom zázemí. Príčinou tohto rastu bude pozitívne migračné saldo doplńnané pôrodnost'ou. Populačný úbytok budú zaznamenávat' hlavne obce na severe a juhovýchode funkčného regiónu. Ide hlavne o obce menej atraktívne pre migrantov, ktoré pre svoju vekovú štruktúru budú zaznamenávat’ zvyšovanie počtu zomretých.

Proces starnutia sa v krátkodobom horizonte pät' rokov nebude výraznejšie prejavovat'. Funkčný región zaznamená nárast hodnoty indexu ekonomického zat’aženia, ale túto ,zát’až“ budú tvorit’ v miernej prevahe deti nad seniormi. Proces starnutia sa prejaví v tzv. jadrových mestských častiach Bratislavy, ako aj na severe a juhovýchode regiónu. Mladnutie populácie sa ukáže v okrajových mestských častiach Bratislavy a hlavne v jej bližšom zázemí.

Pre objektívnost' treba dodat', že výsledky našej populačnej projekcie treba vnímat' v kontexte nasledujúcich obmedzení:

- Projekčný postup vypracovaný Hamiltonom a Perrym je možné aplikovat' na obce funkčného regiónu. Zároveň treba dodat', že výsledky nášho testovania dávajú za pravdu autorom (Swanson et al. 2010, Baker et al. 2013 a Marois a Bélanger 2015), ktorí tvrdia, že pri demograficky dynamických oblastiach (kde kl'účovú rolu hrá migrácia) vykazuje H-P metóda menej presné výsledky. Až 27 obcí vykazuje výrazný (viac ako $10 \%$ ) rozdiel pri porovnaní H-P metódy a kontrolnými projekciami celej populácie.

- Náš postup neumožňuje sledovat' migráciu a úmrtnost' samostatne. Vplyv týchto procesov je možné identifikovat' iba približne, a to nepriamo v kontexte zmeny vekovej štruktúry.

- Ako náhodný prvok sa javí práve migrácia, ktorá je vel'mi t’ažko odhadnutel'ná. Intenzita migrácie v danej obci výrazne súvisí s lokálnym trhom s nehnutel’nost’ami, ktorý sa vel'mi dynamicky mení.

- Plodnost' je značne zjednodušujúca, vychádza len z postupu využívajúceho princíp výpočtu všeobecnej miery. Zároveň treba dodat', že aplikovanie postupov využívajúcich princíp vekovo-špecifických mier nebolo možné, resp. výsledky by boli príliš variabilné.

Aj napriek týmto nedostatkom sme výsledky našej populačnej projekcie použili pri jednoduchej analýze dostupnosti. Konkrétne sme zistili, že medzi rokmi 2019 
až 2024 pribudne v blízkosti dial'ničných úsekov D4 a R7 skoro 19-tisíc obyvatel’ov. Táto analýza má tiež nasledujúce obmedzenia:

- V niektorých obciach predpokladáme rast a v niektorých obciach, naopak, pokles počtu obyvatel'ov. Ich sčítavaním dochádza $\mathrm{k}$ znižovaniu rozdielu medzi prahom a horizontom prognózy daných vzdialenostných zón (hlavne zóna 3,01 až 4,00 km).

- Na vytýčenie vzdialenostných zón sme použili len priame (euklidovské) vzdialenosti a nezohl'adnili možnosti dostupnosti skúmaných dial'ničných úsekov v cestnej sieti za reálnych dopravných podmienok v konkrétnom čase. V takomto prípade by zóny dostupnosti vyzerali pravdepodobne úplne inak. Zohl'adnené by boli len napojenia cez dial'ničné križovatky. Zóny dostupnosti by boli rozsahovo menšie a zohl'adňovali by bariérový efekt rieky Dunaj, či vel'kých priemyselných areálov ako Slovnaft.

- Pre zjednodušenie sme zóny vytýčili len do vzdialenosti $5 \mathrm{~km}$. Je pravdepodobné, že dosahové územie výstavby dial'nice D4 a rýchlostnej cesty R7 je výrazne väčšie.

Naša štúdia potvrdzuje, že za istých dátových podmienok s primeraným metodickým aparátom je možné vykonávat' pomerne presné demografické projekcie na úrovní obcí v kompaktnom regióne. Zároveň sa preukázalo, že demografické projekcie v menej rozsiahlych územiach majú praktické využitie. Výzvu pre takto ladený výskum predstavujú dva smery. Prvým je vylepšovanie metodických postupov demografických projekcií. Druhým je hl'adanie d’alších praktických aplikácií výsledkov takýchto populačných projekcií.

Výsledky projekcie sú dostupné na internetovej adrese: https:// drive.google.com/file/d/19CiPk6kf YidmubQJicAK3CpoCKmhSLD/view? $\underline{\mathrm{usp}}=$ sharing

Príspevok je súčastou riešenia grantového projektu APVV VV-17-0079 s názvom Analýza a prognóza demografického vývoja Slovenskej republiky v horizonte 2080: identifikácia a modelovanie dopadov na sociálno-ekonomickú sféru v rozličných priestorových mierkach. Zároveň chceme pod'akovat' oponentom za relevantné a inšpiratívne pripomienky, ktoré výrazne zvýšili vedeckú hodnotu tohto prispev$k u$.

\section{LITERATÚRA}

BAKER, J., ALCANTARA, A., RUAN, X., WATKINS, K., VASAN, S. (2013). A comparative evaluation of error and bias in census tract-level age/sex-specific population estimates: Component I (Net-Migration) vs Component III (Hamilton - Perry). Population Research and Policy Review, 32, 919-942.

BEZÁK, A. (2000). Funkčné mestské regióny na Slovensku. Geographia Slovaca 15. Bratislava (Geografický ústav SAV).

BEZÁK, A., HOLICKÁ, A. (1995). Komparatívna analýza extrapolačných modelov pre regionálne populačné projekcie. Geografický časopis, 47, 233-246.

BLEHA, B. (2006). Terminologické špecifiká a vybrané teoretické otázky regionálneho populačného prognózovania. Geografický časopis, 58, 61-71.

BLEHA, B., FARBIAKOVÁ, V. (2017). Demografický vývoj a jeho reflexia v programoch hospodárskeho a sociálneho rozvoja. Prípadová štúdia Nitrianskeho a Trnavského kraja. Slovenská štatistika a demografia, 27(4), 36-45.

BLEHA, B., ŠPROCHA, B. (2015). Geografické a demografické determinanty regionálnej diferencovanosti cenzových domácností na Slovensku - analýza a prognóza do roku 2030. Geografický časopis, 67, 219-241. 
BLEHA, B., VAŇO, B. (2007). Prognóza počtu obyvatel'ov SR do roku 2025. Bratislava (Infostat).

BLEHA, B., ŠPROCHA, B., VAŇO, B. (2013). Prognóza vývoja obyvatel'stva v okresoch SR do roku 2035. Bratislava (Infostat).

BLEHA, B., ŠPROCHA, B., VAŇO, B. (2014). Štúdia demografického potenciálu hlavného mesta Slovenskej republiky Bratislava do roku 2050. Bratislava (Infostat).

BLEHA, B., ŠPROCHA, B., VANOO, B. (2018). Prognóz a obyvatel'stva Slovenska do roku 2060 - revizia poznatkov a predpokladov v kontexte pokračujúcej transformácie. Bratislava (Infostat).

BOYCE, M. (1977). Population growth with stochastic fluctuations in the life table. Theoretical Population Biology, 12, 366-373.

BURCIN, B., KUČERA, T. (2007a). Analýz a a prognóza demografického vývoje městské části Brno-Bystrc a perspektivy vývoje obyvatelstva v novém obytném celku Kamechy. Praha (DemoArt).

BURCIN, B., KUČERA, T. (2007b). Prognostický odhad vývoje obyvatelstva městské části Praha-Zličín na obdobi 2007 - 2030. Praha (DemoArt).

BURCIN, B., KUČERA, T., ČERMÁK, Z. (2008). Prognóza vývoje obyvatelstva města Berouna na obdobi 2008 - 2035. Praha (Univerzita Karlova).

BURCIN, B., KUČERA, T., POSPÍŠILOVÁ, L., ŠPAČKOVÁ, P., OUŘEDNÍČEK, M. (2013). Prognóza demografického vývoje spádového území obce Dolní Břežany na obdobi 2012 - 2030. Východiska, předpoklady a základni výsledky prognózy. Praha (Univerzita Karlova).

BURCIN, B., KUČERA, T., POSPÍŠILOVÁ, L., ŠPAČKOVÁ, P., OUŘEDNÍČEK, M. (2013). Prognóza demografického vývoje suburbánní zóny Prahy na období 2012 2030. Východiska, předpoklady a základní výsledky prognózy. Praha (Univerzita Karlova).

DUDǍŠOVÁ, M., ZVERKO, F., SAJKO, L., VALLA, A., ŠTEFKO, L., STANÍKOVÁ, K., LANATOROVÁ, S. (2008). Územný plán obce Senkvice. Bratislava (ÚPn s.r.o).

FIALA, T., LANGHAMROVÁ, J. (2017). Demografická projekce počtu žáků mateřských a základních škol pro malé územní celky. In XLVII. konference České demografické společnosti - Demografické a geodemografické aplikace ve veřejné a komerčni sfére. Jindřichưv Hradec, 18. - 19.5. 2017.

GEOFABRIK. (2019). OpenStreetMap Data Extracts. [Online]. Dostupné na: https//:pwww.openstreetmap.org [cit: 9-9-2019].

HAMILTON, C. H., PERRY, J. (1962). A short method for projecting population by age from one decennial census to another. Social Forces, 41, 163-170.

HOLICKÁ, A. (1997). Empirická analýza regionálnych populačných modelov na úrovní obcí. Geographia Slovaca, 12, 51-60.

ISSERMAN, A. (1993). The right people, the right rates: Making population estimates and forecasts with an interregional cohort-component model. Journal of the American Planning Association, 59, 45-64.

MAROIS, G., BÉLANGER, A. (2015). Analyzing the impact of urban planning on population distribution in the Montreal metropolitan area using a small-area microsimulation projection model. Population and Environment, 37, 131-156.

NOVOTNÝ, L. (2016). Urban development and migration processes in the urban region of Bratislava from the post-socialist transformation until the global economic crisis. Urban Geography, 37, 1 009-1 029.

PATEL, S., D'CRUZ, C., BURRA, S. (2002). Beyond evictions in a global city: peoplemanaged resettlement in Mumbai. Environment and Urbanization, 14, 159-172.

SHRYOCK, H., SIEGEL, J. (1973). The methods and materials of demography. Washington, D.C. (Academic Press).

SLAVİK, V., GRÁC, R., KLOBUČNÍK, M., KOHÚTOVÁ, K. (2011). Development of suburbanization of Slovakia on the example of the Bratislava region. In Marszal, T., ed. Urban regions as engines of development. Warszaw (Polish Academy of Science, Commitee for Spatial Economy and regional Planning), pp. 35-58. 
SMITH, S., NOGLE, J. (1997). An experimental methodology for estimating Hispanic residents for states and counties. Journal of Economic and Social Measurement, 23, 263275.

SMITH, S., TAYMAN, J., SWANSON, D. (2001). State and local population projections: methodology and analysis. New York (Kluwer Academic Publishers).

SMITH, S., TAYMAN,, J., SWANSON, D. (2013). A practitioner's guide to state and local population projections. Dordrecht (Springer).

SWANSON, D., SCHLOTTMANN, A., SCHMIDT, B. (2010). Forecasting the population of census tracts by age and sex: An example of the Hamilton-Perry method in action. Population Research and Policy Review, 29, 47-63.

ŠPAČKOVÁ, P., BURCIN, B. (2017). Rozvoj bytové výstavby v suburbánních oblastech: je možné předvídat demografický vývoj a nároky (nejen) nových obyvatel na sociální infrastrukturu? In XLVII. konference Ceské demografické společnosti - Demografické a geodemografické aplikace ve veřejné a komerční sfére. Jindřichův Hradec, 18. - 19.5. 2017.

ŠPROCHA, B., BLEHA, B., VAŇO, B., BUČEK, J. (2017). Perspektívy, riziká a výzvy demografického vývoja najväčšich miest Slovenska. Bratislava (Infostat).

ŠÚ SR. (2019). DATACube, [Online]. Dostupné na: http://datacube.statistics.sk [cit: 9-92019].

ŠVEDA, M. (2011). Suburbanizácia v zázemí Bratislavy z hl’adiska analýzy zmien krajinnej pokrývky. Geografický časopis, 63, 155-173.

ÚGKKSR. (2016). Uzemné a správne usporiadanie, [Online]. Dostupné na: https:// www.geoportal.sk/sk/zbgis smd/na-stiahnutie/ [cit: 9-9-2019].

WILSON, T. (2016). Evaluation of alternative cohort-component models for local area population forecasts. Population Research and Policy Review, 35, 241-261.

WILSON, T., ROWE, F. (2011). The forecast accuracy of local government area population projections: A case study of Queensland. Australasian Journal of Regional Studies, 17, 204-243.

Zákon č. 293/2014 Z. z. (2014). ktorým sa mení a dopíňa zákon č. 50/1976 Zb. o územnom plánovaní a stavebnom poriadku (stavebný zákon) v znení neskorších predpisov a ktorým sa menia a doplńajú niektoré zákony.

Pavol Ďurče $k$

\section{DEMOGRAPHIC PROJECTION FOR SMALL TERRITORIES: APPLICATION TO MUNICIPALITIES OF THE BRATISLAVA FUNCTIONAL URBAN REGION}

The main aim of this paper is to present the demographic projection at the level of the municipalities of the Bratislava functional urban region. Moreover, the results are used in a simplified analysis of the availability of the D4 and R7 motorways. Hereby we point to the practical usage of the results of our estimation. The motivation for writing this paper is that the Czech and Slovak experts devote relatively little attention to forecasting on a municipal level. The practical usage of such forecasting is relatively large, because population estimation is (or should be) part of municipal planning documents. Maybe for this reason, we may find several papers with this topic (e.g. Burcin and Kučera 2007, Burcin et al. 2008, Bleha et al. 2014, Fiala and Langhamrová 2017, Špačková and Burcin 2017 and Š̉procha et al. 2017).

Our demographic projection is based on the Hamilton-Perry method. The projection threshold is December 31, 2019 and the horizon is December 31, 2024. Specifically, our adjustment to the Hamilton-Perry method is based on the shifting of the number of people in those age categories to an older age. The age structures of municipal populations are varied according to the intensity of the total increase/decrease for individual age categories. 
Testing of accuracy is based on several trend extrapolations of the total population.

The results of our analysis can be summarized as follows. By the year 2024, the population of the functional urban region will increase by 39,000 people. The largest population increase will occur in the periphery of Bratislava and its nearest hinterland. This growth will be due to a positive migration balance with a higher birth rate. Population decline will be mainly in municipalities on the northern and south-eastern part of the functional urban region. These municipalities are less attractive for migrants. The older age structure of these municipalities will also cause increased mortality rates.

The aging will not be more pronounced within five years. In the functional urban region, the economic dependency ratio will increase, but the ratio between children and seniors will be unchanged. The process of aging occurs in the so-called the city's nuclear districts in Bratislava as well as in the north and southeast of the region. The you thing process will occur in the nearest hinterland of Bratislava.

After analysing the availability of the D4 and R7 motorways, we found that between 2019 and 2024, more than 18,000 inhabitants would be close to these motorways (up to 5 $\mathrm{km})$. The challenge for future research is in two areas. The first is to improve methodological forecasting procedures. The second is to look for further practical applications of the results of such population estimates.

The result of our paper can be found at:

https://drive.google.com/file/d/19CiPk6kf YidmubQJicAK3CpoCKmhSLD/view? usp=sharing

cc) (F) Article first received: October 2019

BY NG Article accepted: July 2020 
